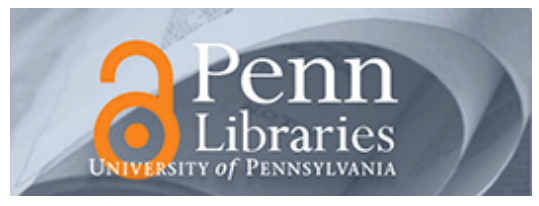

University of Pennsylvania

ScholarlyCommons

Management Papers

Wharton Faculty Research

$1-2015$

\title{
Blacklisted Benefactors: The Political Contestation of Non-Market Strategy
}

Mary-Hunter McDonnell

University of Pennsylvania

Timothy Werner

University of Texas

Follow this and additional works at: https://repository.upenn.edu/mgmt_papers

Part of the Management Sciences and Quantitative Methods Commons

Recommended Citation

McDonnell, M., \& Werner, T. (2015). Blacklisted Benefactors: The Political Contestation of Non-Market

Strategy. Academy of Management Proceedings, http://dx.doi.org/10.5465/AMBPP.2015.289

This paper is posted at ScholarlyCommons. https://repository.upenn.edu/mgmt_papers/200

For more information, please contact repository@pobox.upenn.edu. 


\title{
Blacklisted Benefactors: The Political Contestation of Non-Market Strategy
}

\begin{abstract}
This paper explores whether and how contentious stakeholders can disrupt a firm's non-market strategy. We offer the first systematic study of the effect of public protest on corporate political activity, using a unique database that allows us to empirically analyze the impact of social movement boycotts on targeted firms' campaign contributions. We show that boycotts lead to significant reductions in the amount of targets' campaign contributions and increase the proportion of contributions that politicians refund. These results highlight the importance of considering how a firm's socio-political environment shapes its non-market strategy. We supplement this primary analysis by drawing from social movement theory to extrapolate and test a number of mechanisms that moderate the extent to which movement challenges effectively disrupt corporate political activity.
\end{abstract}

Keywords

boycotts, non-market strategy, social movements

Disciplines

Management Sciences and Quantitative Methods 


\title{
BLACKLISTED BENEFACTORS: The Political Contestation of Non-Market StrategY*
}

\author{
MARY-HunTER MCDONNELL \\ Assistant Professor of Strategy, Economics and Public Policy \\ McDonough School of Business, Georgetown University \\ mhm62@georgetown.edu \\ TIMOTHY WERNER \\ Assistant Professor of Business, Government and Society \\ McCombs School of Business \\ University of Texas at Austin \\ timothy.werner@mccombs.utexas.edu
}

Draft: December 18, 2014

\begin{abstract}
This paper explores whether and how contentious stakeholders can disrupt a firm's non-market strategy. We offer the first systematic study of the effect of public protest on corporate political activity, using a unique database that allows us to empirically analyze the impact of social movement boycotts on targeted firms' campaign contributions. We show that boycotts lead to significant reductions in the amount of targets' campaign contributions and increase the proportion of contributions that politicians refund. These results highlight the importance of considering how a firm's socio-political environment shapes its non-market strategy. We supplement this primary analysis by drawing from social movement theory to extrapolate and test a number of mechanisms that moderate the extent to which movement challenges effectively disrupt corporate political activity.
\end{abstract}

\footnotetext{
* We would like to thank Caroline Flammer, Olga Hawn, Shon Hiatt, Brayden King, Jiao Luo, Jeff Macher, Michael Malbin, and Ed Walker, as well as seminar participants at Wharton, Yale University, Columbia University, the University of Michigan, Chicago Booth, the University of Texas, the University of Maryland, Rice University, Boston University, and Ohio State University for their comments and suggestions on earlier versions of this paper. This paper was previously presented at the 2014 annual meetings of the American Political Science Association and the Strategic Management Society.
} 


\section{Blacklisted Benefactors: The Political Contestation of Non-Market Strategy}

Firms exist in multiple institutional environments, requiring interaction with myriad audiences who often have conflicting expectations and demands (Scott, 1987; Greenwood, 2011). One of the most critical of these audiences is the state, which crafts the rules of the game that define market competition and creates the system of laws and punishments that comprise the formal, regulatory pillar of firms' institutional environments (Scott, 2001). Though legal rules certainly constrain corporate behavior, firms do not passively acquiesce to the iron cage of their regulatory institutions. Rather, work at the intersection of strategy and organization theory provides ample evidence that firms employ a battery of tactics to manage political uncertainty and influence regulatory outcomes (e.g., Fligstein, 1996; Hirsch, 1975; Dunbar \& Wasilewski, 1985; Edelman, Uggen, \& Erlanger, 1999; Rao, Yue, \& Ingram, 2011; Marquis \& Qian, 2014). The broader literature collectively refers to this tactical repertoire as a firm's non-market strategy.

A particularly prolific stream of research in non-market strategy explores corporate political activity, or the pursuit of legislative and regulatory influence through tactics like campaign contributions and lobbying (de Figueiredo, 2009; Hillman, Keim, \& Schuler, 2004; de Figueiredo \& Silverman, 2006; Bonardi \& Keim, 2005; Hadani \& Schuler, 2012; Weymouth, 2012). This work has primarily sought to identify the factors that determine the use and efficacy of political activity. Political scientists, economists, and management scholars have highlighted firm- and industry-level heterogeneity as important predictors of political activity, pointing to factors like firm size, liquid capital, industry concentration, and the extent of industry regulation (e.g., Grier et al., 1994; Hillman, 2003; Macher et al., 2011; Macher \& Mayo, 2012; Weymouth, 2012). Economic sociologists have provided evidence that political activity is also shaped by the 
dense social networks that connect organizations and the managerial elite (e.g., Mizruchi, 1989; 1992; Burris, 2005). And scholars drawing from organizational theory have pointed to differences in culture and behavioral norms as other likely institutional determinants of the business-government interface (Hillman \& Keim, 1995).

Despite this rich, interdisciplinary attention to corporate political activity, we continue to know little about how a company's reputation affects its ability to engage in political strategy and influence regulatory stakeholders. This theoretical gap is surprising given the intimate role that reputational concerns appear to play in the political process. After all, despite its ubiquity, corporate political activity is a contentious subject that draws widespread media coverage and public opprobrium, especially given steady declines since the 1970s in public approval of the role of business in American politics (Smith, 2000). As social actors, government officials strive to build and protect their legitimacy in order to wield and exercise power within their own social field (Pfeffer \& Salancik, 1978; Skocpol, 1985; Suchman, 1995; King, Felin \& Whetten, 2010; Hiatt \& Park, 2013; Werner, 2014). Individual regulators are especially sensitive to threats to their legitimacy because of their continuous, substantial reliance on support from external constituencies (Carpenter, 2001), and elected officials, with their focus on reelection, are similarly cautious. Thus, reputational threats appear likely to adversely affect firms' ability to effectively engage in political activity.

In this paper, we explore this possibility by employing organizational and social movement theory as a lens to understand the relationship between reputational threats and political activity. We propose that non-market strategy is politically contested, meaning that a firm's non-market strategy can be disrupted when contentious stakeholders question the legitimacy of a firm's practices, policies, or products. To test this general proposition, we offer 
the first systematic study of the effect of public protest on corporate political activity, using a unique database that allows us to empirically analyze the impact of social movement boycotts on targeted firms' campaign contributions through their affiliated political action committees (PACs). Results from our analyses confirm that boycotts lead to significant reductions in the amount of targets' campaign contributions. Moreover, we show that boycotts lead to a significant increase in the proportion of targeted firms' contributions that are refunded, thereby being effectively rejected by the politicians they seek to support. These results highlight the important role that the socio-political environment in which a firm is embedded plays in determining firms' freedom to strategically interact with their regulatory environment. We supplement this primary analysis by drawing from social movement theory to extrapolate and test a number of mechanisms that moderate the extent to which movement challenges disrupt corporate political activity.

\section{Background and Theory: Movements and the Disruption of Non-market Strategy}

Work at the nexus of social movement theory and organizational theory explores the increasing prevalence of activist movements that directly target market-based actors to press for changes in corporate products, practices and policies. Although social activists occupy positions of ostensibly little power or authority within the corporate field, they are nonetheless often able to capture the attention of corporate managers and successfully achieve their goals by using contentious tactics like boycotts, protests, and negative media campaigns (King and Pearce, 2011). Recent research suggests that positive outcomes primarily accrue to social movements that are able to use these tactics to disrupt their target's strategic activity (King, 2011). In practice, this disruption takes many forms. Early work in the area focused on protestors' 
disruption of firms' competitive strategy through increasing costs, decreasing consumer demand, and interrupting targets' routines and supply chain processes (Cress \& Snow, 2000; Gamson, 1990; Luders, 2006; Piven \& Cloward, 1977; Rojas, 2006; Seidman, 2007; Luders, 2006; Baron \& Diermeier, 2002). More recent work suggests that activist challenges additionally disrupt their targets' financial market position and social management process, prompting analyst downgrades (Vasi \& King, 2012), spurring investor divestment (Soule, 2009; Soule, Swaminathan, \& Tihanyi, 2013), and threatening a firm's public image and reputation (King, 2008; McDonnell \& King, 2013; King \& McDonnell, 2014).

Despite this considerable body of work exploring the multi-faceted mechanisms through which social movements disrupt their corporate targets, there has been no systematic study of whether and how contentious activists disrupt their targets' political strategy. Recent work does, however, provide preliminary evidence that non-market stakeholders attend to and are influenced by market contention. For example, Ingram and Rao (2004), in their study of anti-chain-store laws in the United States, suggest that activists use political strategies of their own to vie with incumbent firms for regulatory influence. Ingram, Yue, and Rao (2010) provide complementary evidence that firms interpret public protest as a signal of hostile non-market environments with higher regulatory costs. Most recently, Hiatt and Park (2013) argue that regulatory agents interpret public protests as signals of legitimacy risks. Analyzing a sample of petitions for approval of genetically modified plant products, they found that public protests brought against products significantly decreased the likelihood of regulatory approval. Further, they provide evidence that protests caused regulators to rely more heavily on external signals of legitimacy, like the support of powerful industry stakeholders. These results suggest that regulators are 
likely to conclude that companies targeted with higher levels of activism possess compromised legitimacy, which gives rise to a less receptive regulatory environment.

We supplement this prior work by directly exploring the question of whether and how corporate-targeted protest disrupts firms' political strategy. We contend that activist campaigns produce valuable signals of stakeholders' perceptions of an organization that are useful to politicians, just as prior work has suggested they are to investors (King \& Soule, 2007), analysts (Vasi \& King, 2013), and the targeted organizations themselves (Ingram et al., 2010). Social protests bring an organization's reputation and social approval into question. Politicians, we argue, are likely to interpret these reputational threats as indicative of greater associative risk, which we define as the politicians' perceived likelihood of accruing incidental damage by virtue of their mere association with a reputationally compromised organization (Pontikes, Negro, \& Rao, 2010). If we make the uncontroversial assumptions that elected officials are reelection focused and risk averse (Mayhew, 1974), then associative risk should decrease policymakers' willingness to establish a public connection to a firm, due to the threat that it will lead to negative publicity and adverse electoral consequences. Indeed, prior political science research has established that elected officials are less responsive to firms when they believe that being associated with the firm or its policy positions will heighten electoral risks (Smith, 2000). Thus, by threatening their targets' reputations (King, 2008; McDonnell \& King, 2013), social movement challenges are likely to reduce politicians' willingness to establish public ties with the targeted company. In this way, social movement challengers can disrupt their targets' access to non-market strategic options.

Social protest is likely to disrupt visible non-market strategic tactics like corporate campaign contributions through two distinct channels. First, firms that are targeted by social 
activists may anticipate that politicians will be less willing to bear the enhanced risk of associating with them. These firms are also motivated to avoid the additional reputational damage they would incur if politicians publically rejected their contributions. Targeted firms may, therefore, voluntarily reduce their political contributions in the wake of an activist challenge or other reputational threat. Democratic Texas Representative Charlie Gonzalez explicitly articulated this logic just after the BP Horizon explosion in the Gulf of Mexico, saying, "It makes good sense on everyone's part for a company PAC to suspend campaign money during a period of scrutiny..." (Levinthal, 2012). This leads to our first hypothesis:

H1: Firms that are targeted with boycotts will reduce their overall level of political contributions, relative to firms that are not boycotted.

The second way in which social protest disrupts corporate campaign contributions is by increasing the likelihood that politicians will refund the contributions that they receive from targeted firms. Insofar as social movement challenges are interpreted as signals of reduced social approval and increased associative risk, politicians' risk aversion should lead them to be reluctant to keep contributions that they receive from recently targeted companies. Anecdotal evidence abounds to support the more general link between firms' reputational crises and the associative risk borne by politicians with whom they are publically connected. For example, just after the Securities and Exchange Commission filed a lawsuit accusing Goldman Sachs of deceiving its investors, the media produced a veritable laundry list of the politicians who had benefitted from Goldman's support, each of which was being publically challenged by opponents to "do the proper thing" and return the contributions (Mullins \& Spencer, 2010). Goldman's reputational damage essentially risked spilling over to the politicians who maintained their affiliation with the firm, as those who refused to return Goldman's contributions chanced being 
perceived as either complicit in or approving of its behavior. To avoid spillover damage to their own reputations - as well as the adverse electoral consequences of such damage -- politicians receiving money from reputationally compromised firms are more likely to cut ties by shunning the company's support. We can formally state this as:

H2: The proportion of political contributions that are refunded to the contributing firm will increase for firms that are targeted by boycotts, relative to firms that are not boycotted.

Importantly, while H1 captures firms' assessments of the likelihood that their political contributions will be successful, $\mathrm{H} 2$ hones in on our proposed mechanism of associative risk by examining how social protest affects the willingness of politicians to establish or maintain a public connection with a given firm. Further, we believe that this hypothesis offers a particularly conservative test of our hypotheses for two reasons. First, in light of our prior prediction that firms targeted by social movements will be more cautious about making contributions because of their fear of public rejection, any effect we observe in the refunded amounts is likely an understatement of the amount that would have been refunded if targeted companies continued to contribute at their pre-boycott levels. Additionally, given the tremendous resource expenditures required for a political campaign, politicians are typically very reticent to refund the corporate contributions that they receive. This sentiment has colored the judicial interpretation of federal election law, as indicated in the Supreme Court's statement that " $[\mathrm{t}]$ he major evil associated with rapidly increasing campaign expenditures is the danger of candidate dependence on large contributions" (Buckley v. Valeo, 1976). A prominent Republican lobbyist more colorfully illustrated this notion to one of the authors when he was describing the political situation of one of his more controversial client-firms, saying, "Do you know how much [this firm] was hated by the Democrats? They wouldn't take its political money. That is a sentence usually reserved for 
child molesters and prisoners." Further, as average amounts of election expenditures increase with time, so too will the pressure for politicians to keep the corporate contributions they receive, regardless of their benefactor's character. All of this amounts to a likely bias against observable disruptions in refunded PAC contributions over time.

Because we see changes in the proportion of refunds as a more direct test of our overarching theory of disruption through increased associative risk, we focus on this aspect of disruption in teasing out potential moderating mechanisms below.

\section{Moderating Mechanisms}

Past work suggests that contentious activist challenges vary markedly in the extent to which they produce a viable threat to their target's reputation, which leads to systematic differences in targeted firm's direct and indirect responses (King, 2008; McDonnell and King, 2013). Some boycotts go largely unnoticed, whereas others may erupt into large-scale organizational crises for the targeted firm. We suggest that boycotts that provoke more reputational threat are likely to also provoke larger increases in associative risk and, as a consequence, more significant disruptions to the target's ability to access and influence political stakeholders.

King's (2008) political mediation model suggests that the reputational threat produced by a social movement challenge depends on the movement's mobilized resources as well as the characteristics of the targeted firm. Below, we extend this model to the present setting, drawing from past work in social movement theory to tease out the characteristics of boycotts and targeted firms that are likely to moderate the perceived associative risk attendant to a contentious challenge. Additionally, recent work suggests that a targeted firm's defensive response to a 
contentious challenge may ameliorate the extent to which its reputation suffers in the wake of a challenge (McDonnell \& King, 2013; McDonnell, King, and Soule, 2014; McDonnell, 2014). Drawing from this work, we supplement the political mediation model with a discussion of how targets' defensive responses may moderate the disruption of their political strategy.

\section{Characteristics of the Boycott}

Our first proposed moderator of reputational threat is the amount of media attention that a boycott receives. Past research has shown that social movements that generate more media attention represent greater threats to their target (King, 2008; 2011; McDonnell \& King, 2013). Media attention legitimizes activists' challenges and assists activists in mobilizing broad audience support (Koopmans \& Olzak, 2004). We contend that regulatory stakeholders are also likely to notice boycotts that attract more media attention and recognize them as legitimate signals of stakeholder disapproval, leading to increases in associative risk. This suggests:

H3a: Boycotts that receive more media attention will be more likely to lead to increases in the proportion of refunded contributions.

A second moderator of reputational threat is the salience of the issue that is advocated by activists. Social movement theory suggests that activists primarily use contentious tactics to "problematize" a given issue for the public (Benford \& Snow, 2000; King 2008; Maguire \& Hardy, 2009). That is, activists use protest tactics to draw attention to an issue about which the public is largely ignorant or indifferent, seeking to re-frame it in a way that the public will find problematic in order to mobilize support for the activists' reform agenda. Of course, there is wide variance in the types of issues that the public perceives as being most problematic at any given time. Issues must also to some extent compete; it is difficult to rouse the public's support 
for costly environmental reform, for example, when the economy is faltering. Given constraints on their own time and attention, we also expect politicians to focus most keenly on the most salient issues, those that the public currently perceives as being most important. When activists raise concerns about issues that the general public believes to be important, politicians are, in turn, more likely to infer that an association with the firm could risk threatening constituent support, increasing perceived associative risk. Thus:

H3b: Boycotts advocating more salient issues will be more likely to lead to increases in the proportion of refunded contributions.

The extent to which activists can disrupt a corporation's non-market strategy may additionally depend on which point the activists target within the organization's structure, or the structural locus of attack. Often, when firms possess a portfolio that includes potentially controversial brands, they will adopt subsidiary structures that compartmentalize these brands in order to buffer the parent and other brands from the reputational damage associated with the problematic product. For example, Limited Companies has in its history owned both Abercrombie and Fitch and Victoria's Secret, both of which share a storied past with social activists due to controversial product offerings and marketing strategies. But Limited Companies is also the parent of less-controversial retail outlets like Bath and Body Works. Because Limited Companies' structure separates each of its holdings into independently operated and branded retail units, Limited reduces the extent to which an activist challenge against controversial brands like Victoria's Secret will spill over and affect sales of products within less controversial brands like Bath and Body Works.

Activists that contest problematic branded products must make the strategic decision of whether to aim their attack at the parent or the subsidiary. Activists may directly target a specific 
brand or subsidiary because it is the most immediate source of the contested problem or because they themselves do not know of the brand's ultimate owner. For example, in 2013 parent activists made no mention of Limited Brands or its associated holdings when calling for a boycott of Victoria's Secret for allegedly marketing its new 'Bright Young Things' line to middle-school aged girls (ABC News, 2013). However, direct attacks against the parent may be more likely to capture the attention of the managers at the highest orders of a conglomerate's structural hierarchy, and the managers of subsidiaries may have less discretion to respond to the activists' demands (King, 2008). For example, when the Coalition of Immokalee Workers waged a multi-year campaign protesting the exploitative conditions that Taco Bell offered to the indigenous peoples hired to pick its tomatoes, the Coalition directly named Taco Bell's parent, Yum! Brands, as its target. Ultimately, it was the managers of Yum! Brands that conceded to the Immokalee's demands by signing the Fair Food agreement in March of 2005 (Coalition of Immokalee Workers, 2014). The managers of the Taco Bell subsidiary likely lacked the requisite power to make the concessions provided in the agreement.

Because the parent company typically determines a firm's overall political strategy, the locus of attack is also likely to affect the extent to which an activist challenge causes a discernable disruption in strategy. When activists target one brand or subsidiary, the parent company may be shielded from reputational damage, as politicians and members of the public may not be aware of the parent's affiliation with the challenged brands. Attacks directly against the parent, however, may increase potential reputational damage by threatening all of a conglomerate's holdings simultaneously. Politicians and members of the public are also more likely to associate a challenge with a parent company when the challenge is brought against the 
parent company itself. Thus, challenges against a parent are likely to provoke greater associative risk than challenges against subsidiaries.

H3c: Boycotts against parent companies will be more likely to lead to increases in the proportion of refunded contributions.

\section{Characteristics of the Target}

One particularly important firm-level determinant of reputational risk is a firm's position within its field, defined as the "socially constructed arena[] within which actors with varying resource endowments vie for the advantage" (Fligstein \& McAdam, 2012). Firms with higher status within their field hierarchy benefit from more "subjective "standing", than their peer organizations, from which they derive more robust reputations, prestige, and power (2012).

Prior work suggests that reputable firms benefit from an increased 'benefit of the doubt' afforded to them by their stakeholders when they are embroiled in a crisis or scandal (Fombrun, 1996; McDonnell \& King, 2014). Insofar as high field positions are concomitant with higher reputations and esteem, firms occupying more estimable positions within their field are likely to benefit from this 'halo effect.' Like other stakeholders, politicians are likely to interpret challenges in a light more favorable to the targeted firm when the firm has a higher reputation. In turn, we expect challenges against firms with higher reputations to provoke lower perceptions of increased associative risk.

H4a: Boycotts against lower status firms will be more likely to lead to increases in the proportion of refunded contributions.

Regulated firms are typically viewed as being more sensitive to the political process (Masters \& Keim, 1985), and thus, they contribute more on average through their affiliated 
PACs than firms in unregulated industries (Grier et al., 1994). One consequence of this higher level of political engagement is that politicians, through these firms' political activities, as well as their own oversight of these firms' industries, have more information about this subset of firms. In turn, this higher level of information likely leads politicians to have more fixed perceptions of regulated firms that are harder for market activists to disrupt. In contrast, politicians lack information about unregulated firms. As a result, politicians' perceptions of unregulated firms' reputations may be more vulnerable to disruption by market activists, making politicians more likely to distance themselves in the face of signals of associative risk. Thus, we hypothesize that:

H4b: Boycotts against firms in unregulated industries will be more likely to lead to increases in the proportion of refunded contributions.

\section{Target's Defensive Response}

Firms may additionally be able to reduce associative risk in the wake of a social movement challenge by engaging in non-market strategies that provide signals that bolster their reputations and restore social approval. As one Congressman remarked to the press, "What I look for is whether the company is accountable for its mistake, assumes responsibility and takes substantive measures to correct it. Then I'll make a decision about accepting support" (Levinthal, 2012). As this quotation makes clear, the actions that a firm takes to manage stigma in the wake of an activist challenge can affect whether political actors continue to be willing to associate with a firm. We explore two potential strategic responses that companies may take to ameliorate the threat of reputational damage in the wake of a boycott: pro-social claims and direct concession. 
In a study of firm's responses to consumer boycotts, McDonnell and King (2013) provide evidence that many firms respond defensively to protect their reputation after an activist challenge by using increased pro-social claims, or “public expressions of the organization's commitment to socially acceptable norms, beliefs, and activities." Pro-social claims operate to reduce reputational threat by flooding the media with positive images of a firm that dilute the negative claims made by challengers. Because associative risk is predicated on signals of reputational red flags, this type of post-threat impression management should also reduce perceived associative risk within the nonmarket environment by diluting the salience of negative information about the firm. This leads to the hypothesis that:

H5a: Boycotts against firms that engage in less post-threat impression management will be more likely to lead to increases in the proportion of refunded contributions.

A more direct way in which firms can react to ameliorate the reputational threat of an activist challenge is to concede to the activists' demands. In an empirical investigation of the factors leading to corporate concessions to boycotts, King (2008) provided evidence that corporations are more likely to concede when the boycotts provoke an image threat or when the firm's reputation is otherwise vulnerable. Although the direct question of whether concession does indeed quell the reputational threat portended by a contentious challenge is not examined, King's (2008) study suggests that firms are provoked to concede as a defensive play to protect an imperiled public image. For politicians with whom activists' challenges resonate, concession may be taken as a signal that a firm is taking appropriate steps to rectify a reputational vulnerability, reducing the extent to which the activist challenge is interpreted as a signal of enduring associative risk. This suggests: 
H5b: Boycotts against firms that do not concede to activists' demands will be more likely to lead to increases in the proportion of refunded contributions.

\section{Data and Analysis}

\section{Boycott Sample Construction}

We test our hypotheses with a unique, self-constructed database that allows us to track the political campaign contributions and refunded contributions of public companies that are the targets of social movement boycotts. To build our sample of boycotted firms, we performed a manual content analysis of the six largest US newspapers from 1990 to 2007 . The newspapers mined for our sample include the New York Times, Washington Post, Wall Street Journal, Chicago Tribune, USA Today and Los Angeles Times, which provides variation in geographical and substantive focus, as well as editorial page ideology. Using the Factiva, Proquest, and Lexis-nexis databases, coders began by searching the past text of these newspapers for all instances of articles mentioning the words "boycott," "boycotted," "boycotts," or "boycotting." In order to limit the sample to publically traded firms for which financial data was available at the time of the boycott, coders then matched the targeted firms with company-specific quarterly and yearly financial data from COMPUSTAT. In total, the dataset includes 213 distinct boycott events targeting a total of 253 firms. ${ }^{1}$ Full financial data in the period surrounding the boycott were not available for 50 of the targeted firms, reducing the final sample to 203 boycott-target observations.

\footnotetext{
${ }^{1}$ Only one of the 213 distinct boycotts we identify directly relates to corporate political activity, which is unsurprising given that corporate PACs, as access-oriented actors, overwhelmingly give to incumbent politicians rather than only members of one party. The remaining boycotts arise due to corporate practices or events that are exogenous to political activity. Including or excluding the one boycott related to political activity from our sample does not affect our substantive or statistical conclusions.
} 
Our approach continues an established tradition in social movement scholarship of using archival newspaper data to identify instances of social movement tactics (e.g., McAdam \& Su, 2002; Earl, Soule, \& McCarthy, 2003; Earl, Martin, Soule, \& McCarthy, 2004; Van Dyke, Soule, \& Taylor, 2004; King, 2008; McDonnell \& King, 2013; McDonnell, King, \& Soule, 2014). Because of its prevalence, the limitations of this method are also well understood and thoroughly discussed in prior work (Oliver \& Myers, 1999; Oliver \& Maney, 2000; Earl et al., 2004; Ortiz, Myers, Walls, \& Diaz, 2005). For our purposes, use of newspaper media archives presents potential sampling problems that deserve mention here. Past work suggests that newspapers are not fully objective when deciding which movements to cover. For example, they may prefer to include stories about boycotts waging more interesting issues, or those against large, reputable, 'celebrity' firms that are more likely to pique the interest of their readers (e.g., King \& McDonnell, 2014). Thus, it is possible that some boycott events occur but do not receive any newspaper coverage. We would posit, however, that it is unlikely that politicians or targeted companies will be aware of these unreported boycotts. Because we are ultimately interested in how boycotts affect corporate and politician decision-making, conditioning our sample to boycotts reported in major media outlets allows us to better assure that companies and politicians were actually aware of activists' claims, justifying our use of boycotts as an exogenous shock that affects the behavior of politicians and targeted firms.

\section{Matched Sample Construction}

Our first two hypotheses hold that a boycott event will decrease the amount of a targeted firm's gross campaign contributions and increase the proportion of refunded contributions. In order to establish our causal claim, we constructed a quasi-control group of matched, nonboycotted firms so that we could employ a difference-in-differences approach to compare the 
matched sample's PAC contributions and refunds in the pre- and post-treatment period with that of our boycotted sample. This quasi-experimental approach allows us to more confidently infer causality by showing not only that being the target of a boycott correlates with changes in campaign contributions and refunds in the direction we expect but that the patterns we observe for boycotted firms are significantly different than those observed for similar firms that were not boycotted.

We constructed our sample of non-boycotted control firms using coarsened exact matching to match each firm to another firm in the same SIC two-digit industry category with the most similar size (by assets) and status (by ranking in Fortune magazine's annual ranking of the 'Most Admired Companies'). We exact-matched based on industry because the likelihood of regulation - and, accordingly, a company's incentives for participating in political activity varies systematically by industry (Schuler, Rehbein, \& Cramer 2002). We additionally match based on size and status because these variables have been shown repeatedly to be important predictors of the likelihood of being boycotted (e.g., King, 2008; McDonnell \& King, 2013; King \& McDonnell, 2014). By including these variables, we aimed to construct a control sample that was at a similar risk of being boycotted as the treatment sample, so as to reduce the chance that sampling bias explains the observed differences between our treatment and control firms. This helps us to meet the underlying assumption of differences-in-differences analysis that, but for their exposure to the treatment, the treated sample would behave like the matched set, and vice versa. Ultimately, we are left with a 1:1 matched set, including 203 boycotted firms and 203 matches.

\section{Dependent Variables}


The data for our dependent variables come from the Federal Election Commission (FEC). We employed the FEC's transaction-level data for corporate PACs. By way of background, PACs are separate legal funds that are segregated from their affiliated firms' general treasuries. The money raised by corporate PACs must come from a restricted class of individuals that includes the top management team, classified employees, and shareholders, as well as the spouses of these individuals. The affiliated firm may only pay for the operating expenses of the PAC (e.g., filing expenses). Individuals can contribute up to $\$ 5,000$ per calendar year to the PAC, and the PAC can contribute up to $\$ 5,000$ per candidate per election, with primary and general elections counting separately. When an individual contributes money to a PAC, the individual cannot be remunerated for their contribution by the firm, no money can flow back to the individual from the PAC, and the PAC's leadership has control over the contribution process. These last two points are key, as once the money enters the PAC it takes on the sponsoring firm's identity and name, even though the money originated from individuals.

Each quarter, the FEC requires PACs to report transaction-level records of their activity, including amounts refunded, for any transaction greater than $\$ 200$. We aggregate these data into quarterly data by simply summing the relevant collected data (e.g., amount contributed) by PAC and then generating additional indicators, as needed (e.g., proportion refunded $=$ total refunds $/$ total non-netted contributions). Although the FEC requires corporate-linked PACs to list their connected organizations, i.e., the corporation they are connected to, the FEC's data does not provide a link between their data sets and any standard firm unique identifier. Thus, we matched firms and PACs by hand, and in the few cases in which a firm had multiple linked PACs, we aggregated contributions across all of these PACs in each quarter. From this sample, we derive the two dependent variables utilized to test our hypotheses. To test hypothesis 1 , our dependent 
variable is the total amount of federal campaign contributions made from PACs affiliated with a given firm in a given quarter. To test hypotheses 2-5, our dependent variable is the proportion of total federal campaign contributions made from affiliated PACs that were reported as refunded, indicating that they were rejected by the recipient politicians. ${ }^{2}$

\section{Treatment Indicators and the Difference-in-Differences Model Specification}

We test our hypotheses through a series of difference-in-differences analyses. In these analyses, the critical independent variable is referred to as a difference estimator. The difference estimator captures a treatment effect by measuring whether the dependent variable changed at a significantly different rate for the treated group (here, the boycotted companies), as compared to the control group (here, our matched sample). To model the difference estimator within the difference-in-differences analysis testing H1, we transformed our data into a panel dataset where the unit of analysis is the firm-quarter. Each of the 203 boycotted firms and 203 matched firms are observed twice in the dataset: once in the pre-treatment quarter and once in the posttreatment quarter, resulting in a total of 812 observations. To illustrate, if a firm was the target of a boycott in May of 2010, both it and its match from the non-boycotted sample would be observed in the first and third quarters of 2010.

Because the dependent variable, total amount of campaign contributions, is a continuous variable, we employ ordinary least squares (OLS) regression, with standard errors clustered by company-event. The models include a period variable (coded " 0 " before the boycott event and " 1 " after the boycott event) and a treatment variable (coded " 1 " for boycotted firms and " 0 " for the matched firms). The difference estimator is the interaction of the period and treatment

\footnotetext{
${ }^{2}$ To ensure that the refunds we observe resulted from politicians refunding PAC contributions, we examined transaction-level data to rule out the possibility that these refunds resulted from a legal violation, such as the firmlinked PAC contributing beyond the allowed legal limit in that election cycle.
} 
variables. This variable tests whether the change in the dependent variable differs significantly between the treatment and matched samples, allowing us to explore whether the boycott event is the underlying cause of observed changes in the amount of PAC contributions made by targeted firms.

Our models testing changes in the proportion of refunded contributions (H2-5) are similarly constructed, with all firms observed in the pre- and post-treatment periods. However, the proportion refunded dependent variable differs from total contributions dependent variable because, as a proportion, it is bounded between 0 and 1 . Using a proportion in a standard linear regression model such as the OLS to test H2-5 may yield impossible predictions when the dependent variable approaches its minimum and maximum. Thus, in our refund model, we employ the approach developed by Papke and Wooldridge (1996), which uses a logit transformation implemented via a generalized linear model to ensure that predictions of our dependent variable are strictly bound between 0 and 1.

To test hypotheses 3-5, we broke the treatment group into sub-samples which we separately interacted with the period variable to derive independent difference estimators. First, to examine whether the treatment effect differed by the media attention attracted by the boycott, we collected all articles from the six largest US newspapers related to the boycotts in our sample and summed the total number of articles written about each boycott. The amount of media attention ranged from 1 article to 18 articles with a mean of 1.77. The large majority of our sample (70\%) only appeared in the media once: on the day of its initial announcement. We then broke the treatment sample into two separate treatments: boycotts with more media attention and boycotts with less media attention. The more media attention treatment is coded 1 for all treatment firms that was covered in more than one article and the less media attention treatment 
is coded as 1 for all treatment firms for which the initial boycott announcement was the sole coverage. We independently calculated the difference estimator for these sub-samples by separately interacting each with the period variable, as described above.

We measured the salience of the boycotter's claims by using data from Gallup's 'Most Important Problem' poll. Gallup conducts this poll quarterly on a randomized sample of American voters who are asked open-endedly to name "the most important problem facing this country today." The data report each individual problem that was listed, along with the proportion of polled individuals who chose it. In the first quarter of 2014, for example, the most often cited problems were unemployment, government dissatisfaction, and the general economy, and lesser cited problems included abortion, gun control, and corporate corruption. In total, 47 distinct problems were cited during this quarter. Using these data, we sorted the treatment sample into two groups: higher issue salience and lower issue salience. Treated firms were sorted into the higher issue salience group if the issue being waged in the boycott was among those reported in the 'Most Important Problem' poll. All other treated firms were sorted into the lower issue salience category.

To explore whether the treatment effect differed by locus of attack for treated firms, we split the treatment sample into two categories: parent and subsidiary. The parent category was coded as 1 for all boycotts waged against a parent company, and 0 otherwise. The subsidiary category was coded as 1 for all boycotts waged against a subsidiary, and 0 otherwise. Again, we independently calculated the difference estimator for these sub-samples by separately interacting each with the period variable.

To explore whether the treatment effect differed by the status of treated firms, we split the treatment sample into two categories: high status and low status. As a proxy for corporate 
status, we used Fortune magazine's annual 'Most Admired Companies' index. The Fortune 'Most Admired' index is a ranking of corporate prestige based on surveys of the executives of an organization's peer firms (Fombrun \& Shanley, 1990; Bermiss, Zajac, \& King, 2013). The rankings are also a popular proxy for corporate status and prestige (Roberts \& Dowling, 2002; King, 2008; Pfarrer, Pollock \& Rindova, 2010; McDonnell \& King, 2013), representing “the most widely used in the empirical research arena" (Sabate \& Puente, 2003). Firms are ranked on a scale ranging from 0 to 10 and those firms scoring the highest within their industry are reported in the annual 'Most Admired Companies' list. The rankings have a natural one-year lag, being based on surveys collected in the prior year. We sorted targeted firms into the high status category if they were listed in the Fortune index in the year of the boycott and into the low status category if they were not. We then calculated difference estimators for each of these categories by independently interacting them with the period variable.

To examine whether the treatment effect differed by whether the boycotted firm was in a regulated industry, we split the treatment sample into two categories: regulated industry and unregulated industry. We sorted firms into the regulated or unregulated industry category using the classification by two-digit SIC code provided in prior work (Weiss \& Klass, 1986; Danos \& Eichenseher, 1982; Hogan \& Jeter, 1999). We independently calculated the difference estimator by separately interacting each category with the period variable.

To examine whether the treatment effect differs by a firm's post-boycott impression management, we collected data on all firm's pro-social claims in the six months following a boycott announcement. Using Factiva's major PR newswires database, we searched for all press releases issued by a targeted firm in the six months after a boycott's announcement. We then read through each result and identified examples of pro-social claims, or communicated claims 
of corporate social actions that extend beyond the direct transactional interests of the firm to aid the firm's external stakeholders or communities (McDonnell \& King, 2013; Marquis et al., 2007). Using this data, we split the treatment sample into two categories: high impression management and low impression management. The low impression management category is coded " 1 " for all targeted firms that did not issue any prosocial claims in the six months following the boycott, while the high impression management category is coded " 1 " for all targeted firms that issued one or more prosocial claim in the six months after the boycott. We independently calculated the difference estimator for these sub-samples by separately interacting each with the period variable.

Finally, to test whether the difference estimator varies by concession, we split the treatment sample into two categories, concession and no concession, which are each binary variables capturing whether a targeted firm conceded to the boycotters' demands. Following King (2008), a concession was defined in the coding process as "a recognition by the corporation of the boycotters' demands and a public expression of conformity to those demands." To identify when a concession occurred, we searched for and read all additional newspaper coverage of the boycotts in our sample. Our coding scheme rests on the assumption that corporations that intend to concede to activists will do so publically, given that activists' challenges are launched in the public arena. Targeted firms in our sample conceded about $23 \%$ of the time, which is similar to the concession rate found in prior samples of boycotted firms (e.g., Friedman, 1985: 26\%; King, 2008: 28\%). We independently calculated the difference estimator for the concession and no-concession sub-samples by separately interacting each with the period variable. 
Table 1 provides a descriptive breakdown and correlation table for the aforementioned treatment sub-samples. The low correlations between these variables provide evidence that each of our proposed moderating mechanisms describes a discrete sub-sample of treated firms.

[Insert Table 1 Here]

\section{Control Variables}

Across all models, we include a battery of control variables that previous research demonstrates are associated with corporate political activity. In all models predicting the proportion of refunded contributions, we include a control for the logged total PAC contributions in the same quarter. To account for systematic temporal patterns in giving as a result of election cycles, we include year and quarter fixed effects, as well as a separate control for the quarter just prior to an election, when we would expect contributions to spike and politicians to be more reluctant to refund contributions. To capture differences in the extent of firms' relationships with regulators, we include a binary variable that captures whether a firm operates in a regulated industry, using the classification by two-digit SIC code provided in prior work (Weiss \& Klass, 1986; Danos \& Eichenseher, 1982; Hogan \& Jeter, 1999). To account for likely differences in the proclivity of disparate political parties to refund contributions, we include a variable company political alignment - that is equal to the difference between the total contributions made to Republicans and Democrats, divided by the total contributions. This variable ranges from 1 to -1 , with firms that only gave to Republican candidates receiving a score of 1 and firms that only gave to Democratic candidates receiving a score of -1 . We control for firm performance by including return on equity $(R O E)$. Given that, as described above, the number of contributors to a firm's PAC correlates with its total number of employees, we include the 
logged number of employees as our general proxy for corporate size. Each of the corporate political alignment, ROE, and logged number of employees variables is lagged one quarter to allow for better causal estimation. To capture differences in baseline reputation, we include the raw score for each firm in annual Fortune 'Most Admired' rankings, which range from 0-10. Following the assumption that politicians are less likely to have solid information about the reputation of firms that do not appear in the 'Most Admired' rankings, we assign all firms that are not included in the rankings a reputation score of 0 . Finally, because firms whose primary operations are in different states are likely to face very different state-level electoral pressures in a given election cycle, we include a fixed effect for the state in which each firm is headquartered.

Descriptive statistics for and correlations between the control variables used in our analyses are provided in Table 2 below.

[Insert Table 2 Here]

In an ideal matched sample, control firms are identical to treated firms in all relevant pretreatment characteristics (Heckman, Ichimura, \& Todd, 1998). To probe the adequacy of our matched sample, Table 3 provides descriptive statistics comparing the treatment sample to the matched sample across all pre-treatment explanatory and control variables utilized in our models. $T$-tests for differences in means were run between the groups on all variables. As shown in the final column of Table 3, these $t$-tests confirmed that the treatment sample does not significantly differ from the matched sample on any of these variables. Our sample of boycotted firms is marginally significantly larger in terms of its number of employees $(p=.08)$, but our models are not affected by controlling for this variable. These results lend credence to the matched sample's adequacy as a reliable comparison group for purposes of our difference-in-differences analyses. 


\section{Results}

Models testing hypotheses 1 and 2 are shown in Table 4, below. Model 1 tests for changes in sample firms' overall PAC contributions. The control variables in model 1 further indicate that firms give higher contributions in general when they operate in regulated industries, occupy a higher status, lean more toward a conservative political alignment, and have more employees. Additionally, H1 is supported by the model: The difference estimator is negative and statistically significant, suggesting that boycotted firms did indeed reduce their amounts of PAC contributions in the post-boycott period, relative to the matched sample.

Model 2 tests for changes in the proportion of PAC contributions that were refunded to sample firms by the recipient politicians. Here, the control variables indicate that firms have higher amounts refunded when they are larger and give more money overall. Additionally, the corporate political alignment variable in this model is negative and significant. This suggests that, as might be expected in light of the pro-business orientation of the Republican Party, firms have a smaller proportion of contributions refunded when they give more to conservative candidates. The difference estimator in model 2 is positive and significant, providing evidence that boycotted firms did have a larger increase in the amounts of refunded contributions in the post-boycott period, relative to the matched firms. Thus, H2 is supported by the model. Interestingly, the period variable in model 2 is verging on significance, providing some indication that the non-boycotted firms in our sample may actually enjoy a decrease in the amount of refunded contributions over time.

[Insert Table 4 Here]

To assist with the interpretation of the refund results, Figure 1 provides a bar graph of the pre- to post-treatment proportions in refunded contributions for the boycotted firms and the 
matched sample. As can be seen in the graph, the treatment sample receives significantly higher refunds than the control sample in the quarter following the boycott. The non-boycotted firms actually enjoy a decrease in the amount of refunded contributions, consistent with the decreasing trends in refunds over time that one would expect in light of the increasing campaign expenditures more generally.

\section{[Insert Figure 1 Here]}

As discussed above, our estimated effect derived from this difference-in-difference analysis is limited to the quarter just after the boycott. This modeling choice likely leads to a conservative estimate, as we ignore both that portion of the cumulative effect that occurs in the quarter of the boycott, as well as the possibility that the effect is felt by firms for more than one quarter after the boycott. We probe this possibility in Figure 2, below, where we highlight the trends in the proportion of total PAC contributions that were refunded. ${ }^{3}$ The figure plots the mean proportion of PAC contributions refunded for both our treatment and control groups (once we stack them in time around their boycotted quarter) from four quarters prior to the boycott to four quarters after it. Two key points stand out: first, the trends across the two groups are roughly parallel in the pre-boycott period, satisfying the key assumption of our difference-indifferences design that trends in our dependent variable do not significantly differ between the treatment and control groups in the absence of the treatment. Second, the gap that opens during the boycott quarter and remains open (if narrowing) afterward provides suggestive evidence that the effect endures beyond the immediate quarter following the boycott.

\section{[Insert Figure 2 Here]}

\footnotetext{
${ }^{3}$ Pre- and post-treatment trends for the average total PAC contributions (logged) are similar in that they are parallel across our treatment and control groups pre-boycott, and a gap between these groups opens during and remains after the quarter of the boycott. We plot the proportion refunded for space concerns and also due to our use of it in tests of $\mathrm{H} 2$ and all parts of $\mathrm{H} 3, \mathrm{H} 4$, and $\mathrm{H} 5$.
} 
Models of our proposed boycott-specific mechanisms moderating the extent of a boycott's nonmarket disruption (H3a-3c) are provided in table 5. Model 1 tests whether boycotts that receive more media attention are likely to experience higher levels of disruption (H3a). Here, we find that the difference estimator for boycotts that receive higher levels of media attention is positive and significant, suggesting that firms that are targeted by boycotts receiving two or more articles in the mainstream press experience an increase of about $3.39 \%$ in the amount of their political contributions that were refunded in the quarter after the boycott. The difference estimator for boycotts that receive less media attention is, on the contrary, not significantly different from 0 . This provides support for our hypothesis $3 \mathrm{a}$ by indicating that boycotts that present more of a reputational threat are more likely to lead to significant disruption of a targeted firm's non-market strategy.

Model 2 of Table 5 tests H3b, suggesting that boycotts that challenge issues that are recognized as more salient or important to the public are more likely to provoke higher levels of disruption in their targeted firms. This hypothesis receives support in the model. The difference estimator for boycotts that waged issues listed in Gallup's 'Most Important Problem' poll is significant and positive, suggesting that firms targeted by these boycotts experienced around a $2.12 \%$ increase in the amount of their political contributions that was refunded in the quarter after the boycott. The difference estimator for firms targeted by boycotts waging issues that were not listed in the Gallup poll is not significantly different from 0.

Model 3 of Table 5 tests our final boycott-specific moderating mechanism (H3c), which suggests that boycotts that target a parent company (rather than a subsidiary or single brand) will be more likely to provoke non-market disruption for the targeted firm. Here, we find that the difference estimator for the boycotts targeting a parent company is positive and significant, 
indicating that parent companies targeted directly by boycotts suffered around a $2.00 \%$ increase in the amount of their political campaign contributions that was refunded in the quarter after the boycott, relative to other firms. Boycotts targeting a subsidiary or brand did not provoke a significant increase in the amount of contributions refunded to their targets.

[Insert Table 5 Here]

Table 6 provides the results for our final set of models testing the target-specific mechanisms of disruption (H4a-b), as well as the moderating power of post-boycott strategies employed by the targeted firm (H5a-b). Model 1 of Table 6 tests whether low-status firms are likely to suffer higher levels of non-market disruption when targeted (H4a). The model supports this hypothesis. The difference estimator suggests that low status boycotts experience around a $2.94 \%$ increase in the amount of their refunded contributions in the quarter after the boycott $(p<$ .01). The difference estimator for firms higher status firms is, however, not significantly different from zero.

Model 5 tests $\mathrm{H} 4 \mathrm{~b}$ that firms operating in unregulated industries will experience higher levels of disruption as a result of being boycotted, in the form of increased refunded political contributions. Here, we find that boycotts in unregulated industries experience a significant (roughly $1.81 \%$ ) increase of refunded contributions in the quarter after the boycott, relative to other firms. To the contrary, we find no evidence of a significant increase in refunded contributions for the boycott targets that operate in regulated industries. Thus, H4b is supported in the model.

Hypothesis 5a argues that firms that fail to engage in post-boycott impression management will experience higher levels of disruption when targeted by a boycott. Model 6 tests this hypothesis. Here, we find that boycotts of firms with low post-threat impression 
management see a significant increase in refunded contributions. Targets in this category experienced around a $2.11 \%$ increase in their refunded contributions, relative to other firms $(p<$ .05). The difference estimator for firms that engaged in post-boycott impression management is not significant, suggesting that firms that actively made pro-social claims in the wake of a boycott were no more likely than their matched firms to experience refunded contributions.

Finally, Model 7 of Table 6 tests our hypothesis that firms that do not concede to a boycott are more likely to experience nonmarket disruption (H5b). The models do not support this hypothesis. The difference estimator for non-conceding firms is not significant, suggesting that these targets that did not concede to a boycott were no more likely than the control firms to experience increased refunded political campaign contributions. Interestingly, the difference estimator for targets that did concede to a boycott is positive and verging on significance, providing some indication that firms that do concede to a boycott may be more likely to experience nonmarket disruption in the form of refunded campaign contributions. This finding provides support to claims made in prior work that concession may lead to higher levels of reputational risk by recognizing and validating the activists' disparaging claims (McDonnell \& King, 2013), whereas a more indirect tactics, such as making a pro-social claim, does not.

[Insert Table 6 Here]

\section{Discussion and Conclusion}

Our paper contributes most directly to two active streams of research: social movement theory and non-market strategy. We contribute to social movement research by exploring the manner in which social movement challenges disrupt corporate non-market strategy. Our study provides evidence that the political arena offers an unexplored dimension through which 
contentious activists gain leverage over their corporate targets. Principally, by increasing the risk that guilt by association may harm political actors through the use of boycotts, activists impede their targets' access to and thus influence over regulatory and political stakeholders. We articulate and find evidence for two different mechanisms through which these constraints occur. First, firms self-constrain their behavior: the average boycotted firm-connected PAC reduces its contributions by approximately $1.6 \%$ in the quarter after they are boycotted. We hypothesize that this behavior is driven both by a lack of willing recipients, as well as an acknowledgement by a firm's management that its contributions may do more harm than good to candidates it supports. Second, we also find that politicians increasingly reject contributions from controversial firms, with the average boycotted firm seeing the proportion of its contributions that are refunded increase by 0.016 , which, on average, represents a doubling of this amount.

Although the magnitude of these effects may appear relatively small, the boycotts from which they stem are not purposively focused on constraining firms' non-market practices but rather on altering other practices of the target firms. Thus, the substantive impact of our findings are best interpreted as lower bounds or conservative estimates of the effects of social movements on political contributions and non-market strategy more broadly. If social movement activists targeted firms specifically for their prior engagement in electoral politics, then we would expect the magnitude of boycotts' effects to be substantially greater.

In addition to providing evidence for the disruptive potential of contentious challenges, we also examine characteristics of the boycotts and impacted firms that might enhance or ameliorate the threat of disruption, such as media attention and impression management. These investigations extend the work of economic sociologists who have previously pointed to the importance of considering the complex social systems in which firms are embedded as an 
important predictor of corporate political activity (e.g., Mizruchi \& Koenig, 1986; Mizruchi, 1989; Burris, 2005). Boycotts are more likely to cause disruption when they attract more media attention, target their locus of attack at the parent-firm level, and protest more salient issues. Firm-level characteristics that positively moderate disruption include possessing a high-status and operating in an unregulated industry. Finally, we provide evidence that disruption is more likely to occur when targeted firms fail to engage in defensive impression management in the wake of a boycott, consistent with McDonnell and King's (2013) claim that post-boycott impression management operates to reduce reputational damage.

This paper also contributes to existing non-market strategy research by exploring how the contentiousness of a firm's stakeholder environment can constrain the tactics firms may employ. The findings additionally have broader implications for our understanding of the power of business as a political actor. First, we find that social movement challenges can disrupt the availability of mainstream corporate political strategies, in effect making non-market strategy less attractive for firms (Bonardi et al., 2005; Oliver \& Holzinger, 2008), especially when considered as a substitute for market strategy, which has previously been shown as subject to similar disruptions. Any limitation on firms' ability to engage in electoral politics has a subsequent effect of their ability to help shape which individuals hold office, which political party gains majority status, and thus, which set of political actors controls the policy agenda and policy outcomes. Further, by specifically constraining direct contributions from firms' affiliated PACs to individual candidates, activists leave firms with only one other tactical option for engaging in electoral politics - independent expenditures - that cannot be coordinated with the candidate, are unproven in their effectiveness, and have been subject to heavy criticism since 
being allowed in an unlimited and potentially undisclosed fashion by Citizens United, which was decided in 2010, three years after our sample period ends.

Second, our findings reveal an important, if small and temporary, limit on the instrumental power of business (Lindblom, 1977). As a result of this limitation, firms may have to adjust their non-market strategies either by relying to a greater degree on their structural (e.g., Lindblom, 1982; Block, 1977) or persuasive powers (Smith, 2007) or by putting a greater emphasis on other political instruments/tactics that have proven successful for them, such as regulatory and legislative lobbying (Baumgartner et al., 2009) or grassroots mobilization (Walker, 2014). Of course, these other instruments, unlike electoral politics, aim largely not to influence whom holds office and thus controls the policy agenda but rather to persuade those in already in office or to affect policy change directly through initiatives or referenda.

Finally, in bringing together social movement theory and non-market strategy, we contribute to the broader search for institutional variants that help to explain differences in corporate political behaviors (Hillman \& Keim, 1995; Hillman \& Hitt, 1999; Bonardi et al., 2005; Macher et al., 2011; Weymouth, 2012). The extent to which activists disrupt a corporation's political strategy may also carry over to a firm's market performance, insofar as higher political contributions or tighter political connections lead to outperforming stock returns and survival benefits (e.g., Carroll, Delacroix, \& Goodstein, 1988; Hannan \& Freeman, 1977; Burt, 1992; Getz, 1997; Pfeffer \& Salancik, 1978; Hillman, 2005; Gulen, Cooper \& Ovtchinnikov, 2010; Hadani \& Schuler, 2012). Thus, the process explored here has potentially far-reaching strategic implications for firms that operate in contentious social environments.

There are two key limitations to this paper that deserve future study. First, although we document that social movement-led boycotts constrain firms' political contributions, we do not 
examine whether or how firms adjust their non-market strategies as a result of market contention. For example, within the realm of electoral politics, as we discussed earlier, firms may shift from making PAC contributions to making independent expenditures. Additionally, other individual actors connected to a firm, such as its top management team, may adjust their personal giving strategies in service of a firm when its PAC is constrained (e.g., Richter \& Werner, 2013). Firms may alternatively shift from electoral non-market strategies to informational strategies focused on the provision of politically and policy relevant information via lobbying, or they may seek to develop connections to policymakers by employing their former colleagues or staff members.

The second limitation relates to the first in that should firms adapt their strategies to take advantage of the loopholes in disclosure created by Citizens United, then those firms targeted by social movement activists may still be able to engage in electoral politics without tainting their allies via guilt by association. Of course, for this strategy to work, firms will have to find a way to communicate discreetly that they supported a politician in this manner without violating the legal prohibition on coordination between candidates and those making independent expenditures on their behalf. We note, however, that existing political science research (e.g., Hamm et al., 2012; Werner \& Coleman, 2014) provides little evidence to suggest that businesses either engage in independent expenditures at significant rates or do so other than in a manner that is contrary to shareholders' interests.

By viewing corporate political activity through the lens of organizational theory and social movement theory, we see this project as an answer to Walker and Rea's (2014) recent call for the reinvigoration of sociological inquiry into the study of corporate power and influence. More significantly, we see this study as drawing together two fields that should be in 
conversation with one another, given the rapidly growing importance of external stakeholders to firms' market and non-market strategies. 
Figure 1: Refunded Contributions Before and After a Boycott Announcement

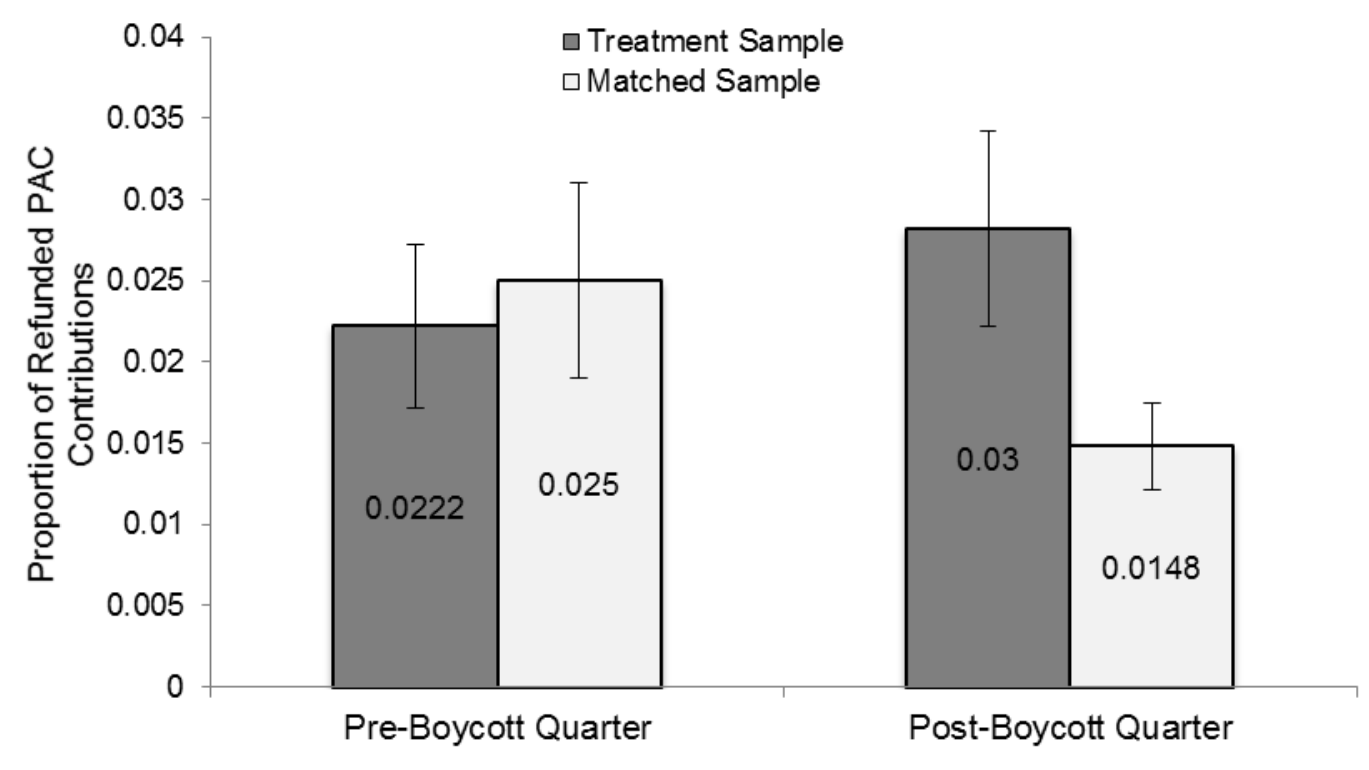


Figure 2: Quarterly Proportion of PAC Contributions Refunded Around Corporate Boycotts

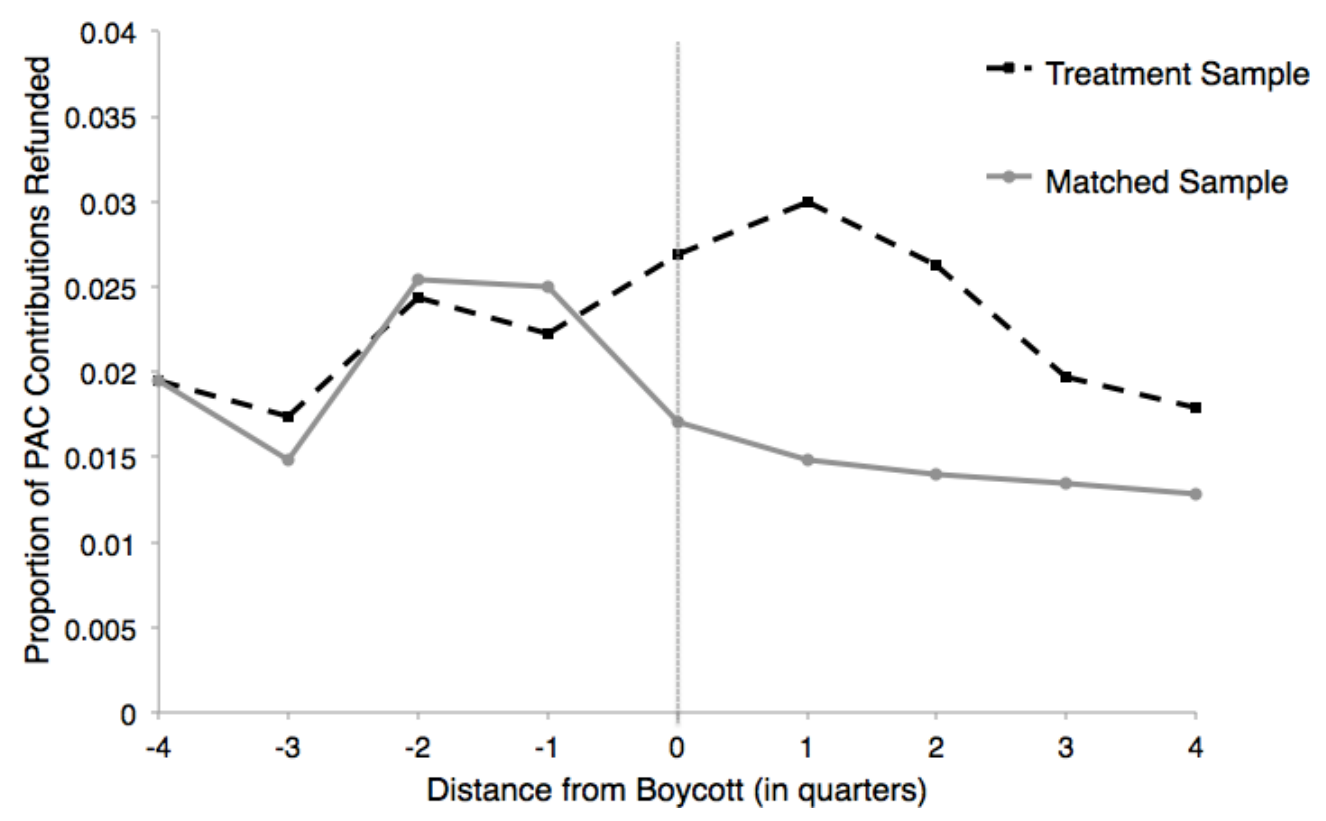


Table 1: Summary Statistics of Treatment Sub-Categories

\begin{tabular}{|c|c|c|c|c|c|c|c|c|c|c|c|}
\hline & & Mean & S.D. & Min 1 & $\operatorname{lax}$ & 1 & 2 & 3 & 4 & 5 & 6 \\
\hline 1 & Boycott: More Media Attention & 0.280 & 0.450 & 0 & 1 & & & & & & \\
\hline 2 & Boycott: More Claim Legitimacy & 0.645 & 0.479 & 0 & 1 & 0.2121 & & & & & \\
\hline 3 & Boycott: Parent Company & 0.665 & 0.473 & 0 & 1 & 0.0383 & 0.1006 & & & & \\
\hline 4 & Boycott: High Status & 0.793 & 0.476 & 0 & 1 & 0.0657 & 0.0618 & 0.0865 & & & \\
\hline 5 & Boycott: Unregulated Industry & 0.429 & 0.406 & 0 & 1 & 0.1285 & -0.0282 & -0.2299 & -0.1882 & & \\
\hline 6 & Boycott: Low Impression Management & 0.227 & 0.496 & 0 & 1 & 0.1383 & -0.0058 & 0.0681 & 0.3449 & 0.0102 & \\
\hline & Boycott: Concession & 0.226 & 0.420 & 0 & 1 & 0.3064 & 0.0364 & -0.0519 & -0.0116 & 0.0626 & 0.0762 \\
\hline
\end{tabular}

Table 2: Summary Statistics and Correlations

\begin{tabular}{|c|c|c|c|c|c|c|c|c|c|c|}
\hline Variable & Mean & Min & Max & SD & 1 & 2 & 3 & 4 & 5 & 6 \\
\hline 1 Total PAC Contributions & $25,686.66$ & $-5,500$ & 413,000 & $47,211.29$ & 1.00 & & & & & \\
\hline 2 Refund Proportion & 0.022 & 0 & 0.875 & 0.0767 & 0.056 & 1 & & & & \\
\hline 3 Regulated Industry & 0.203 & 0 & 1 & 0.402 & 0.014 & 0.025 & 1 & & & \\
\hline 4 Reputation & 4.464 & 0 & 8.83 & 3.363 & 0.277 & 0.084 & 0.057 & 1 & & \\
\hline 5 Corporate Political Alignment & 0.208 & -1 & 1 & 0.751 & 0.045 & -0.077 & 0.088 & 0.105 & 1 & \\
\hline $6 \mathrm{ROE}$ & 0.00543 & -12.039 & 4.798 & 0.557 & 0.034 & 0.022 & 0.062 & 0.073 & 0.029 & 1 \\
\hline 7 Logged Employees & 3.841 & -4.71 & 7.649 & 1.604 & 0.335 & 0.11 & -0.037 & 0.406 & 0.129 & 0.026 \\
\hline
\end{tabular}


Table 3: Comparison of Pre-Treatment Variables for Treatment and Matched Samples

\begin{tabular}{|c|c|c|c|c|c|}
\hline \multirow[b]{2}{*}{ Pre-Treatment Variable } & \multicolumn{2}{|c|}{ Treatment Sample } & \multicolumn{2}{|c|}{ Matched Sample } & \multirow[b]{2}{*}{ T-test } \\
\hline & Mean & SD & Mean & SD & \\
\hline Total PAC Contributions & 24323.35 & 46070.17 & 26000.05 & 47047.87 & 0.71 \\
\hline Proportion Refunded & 0.022 & 0.085 & 0.025 & 0.08 & 0.73 \\
\hline Reputation & 4.54 & 3.39 & 4.38 & 3.33 & 0.63 \\
\hline Corp. Political Alignment & 0.167 & 0.771 & 0.192 & 0.736 & 0.74 \\
\hline ROE & 0.186 & 0.192 & 0.215 & 0.207 & $\mathbf{0 . 8 8}$ \\
\hline Logged Employees & 3.976 & 1.49 & 3.695 & 1.72 & 0.08 \\
\hline Logged Assets & 9.442 & 1.793 & 9.163 & 1.692 & 0.11 \\
\hline
\end{tabular}


Table 4: Difference-in-Differences Models Exploring the Effect of Being Boycotted on Political Campaign Contributions

\begin{tabular}{|c|c|c|}
\hline Variables & $\begin{array}{l}\text { Model 1: } \\
\text { Logged PAC } \\
\text { Contributions }\end{array}$ & $\begin{array}{l}\text { Model 2: } \\
\text { Proportion Refunded }\end{array}$ \\
\hline \multirow[t]{2}{*}{ Treatment: Boycott } & -0.754 & -0.00448 \\
\hline & (0.493) & $(0.006)$ \\
\hline \multirow[t]{2}{*}{ Period } & 0.269 & $-0.00866+$ \\
\hline & $(0.178)$ & $(0.005)$ \\
\hline $\begin{array}{l}\text { Difference Estimator } \\
\text { (Treatment x Period) }\end{array}$ & $\begin{array}{l}-\mathbf{0 . 5 0 0} * \\
(0.245)\end{array}$ & $\begin{array}{l}\text { 0.0161* } \\
(0.008)\end{array}$ \\
\hline \multicolumn{3}{|l|}{ Controls } \\
\hline \multirow[t]{2}{*}{ Regulated Industry } & $2.083 * *$ & 0.00495 \\
\hline & $(0.708)$ & $(0.005)$ \\
\hline \multirow[t]{2}{*}{ Reputation } & 0.181* & -0.000537 \\
\hline & $(0.088)$ & $(0.001)$ \\
\hline \multirow[t]{2}{*}{ Corporate Political Alignment } & $0.728 * *$ & $-0.0120 * *$ \\
\hline & $(0.258)$ & $(0.004)$ \\
\hline \multirow[t]{2}{*}{ ROE } & 0.0095 & 0.00145 \\
\hline & $(0.209)$ & $(0.002)$ \\
\hline \multirow[t]{2}{*}{ Logged Employees } & $1.353 * * *$ & $0.00308 *$ \\
\hline & $(0.179)$ & $(0.001)$ \\
\hline \multirow[t]{2}{*}{ Log Total PAC Contributions } & & $0.00246 * * *$ \\
\hline & & $(0.001)$ \\
\hline Year Fixed Effects & YES & YES \\
\hline Quarter Fixed Effects & YES & YES \\
\hline State Fixed Effects & YES & YES \\
\hline \multirow[t]{2}{*}{ Constant } & 0.887 & $-0.0193+$ \\
\hline & $(1.634)$ & $(0.010)$ \\
\hline $\mathbf{N}$ & 812 & 812 \\
\hline
\end{tabular}

$+p<0.10 ; * p<0.05 ; * * p<0.01 ; * * * p<0.001$ 
Table 5: Models Exploring Boycott-Specific Mechanisms of Nonmarket Disruption

\begin{tabular}{|c|c|c|c|}
\hline Variables & $\begin{array}{l}\text { Model 1: } \\
\text { Media Attention }\end{array}$ & $\begin{array}{l}\text { Model 2: } \\
\text { Issue Salience }\end{array}$ & $\begin{array}{l}\text { Model 3: } \\
\text { Locus of Attack } \\
\text { (Parent/Subsidiary) }\end{array}$ \\
\hline \multirow[t]{2}{*}{ Boycott: More Media Attention } & -0.00874 & & \\
\hline & $(0.007)$ & & \\
\hline \multirow[t]{2}{*}{ Boycott: Less Media Attention } & -0.00399 & & \\
\hline & $(0.006)$ & & \\
\hline Dif: Boycott More Media Attention & $\begin{array}{l}\text { 0.0339* } \\
(0.014)\end{array}$ & & \\
\hline Dif: Boycott Less Media Attention & $\begin{array}{l}\mathbf{0 . 0 1 1 2} \\
(0.007)\end{array}$ & & \\
\hline \multirow[t]{2}{*}{ Boycott: Higher Issue Salience } & & -0.0022 & \\
\hline & & $(0.007)$ & \\
\hline \multirow[t]{2}{*}{ Boycott: Lower Issue Salience } & & -0.0081 & \\
\hline & & $(0.007)$ & \\
\hline \multicolumn{2}{|l|}{ Dif: Boycott Higher Issue Salience } & $\begin{array}{l}\text { 0.0212* } \\
(0.010)\end{array}$ & \\
\hline \multicolumn{2}{|l|}{ Dif: Lower Issue Salience } & $\begin{array}{l}\mathbf{0 . 0 0 6 5 5} \\
(0.007)\end{array}$ & \\
\hline \multirow[t]{2}{*}{ Boycott: Targeted a Main Company } & & & -0.00426 \\
\hline & & & $(0.006)$ \\
\hline \multirow[t]{2}{*}{ Boycott: Targeted a Subsidiary } & & & -0.00483 \\
\hline & & & $(0.007)$ \\
\hline \multicolumn{3}{|l|}{ Dif: Boycott of Parent Company } & $\begin{array}{l}\mathbf{0 . 0 2 0 0} * \\
(0.008)\end{array}$ \\
\hline \multicolumn{3}{|l|}{ Dif: Boycott of Subsidiary/B rand } & $\begin{array}{l}\mathbf{0 . 0 0 8 1 6} \\
(0.010)\end{array}$ \\
\hline \multirow[t]{2}{*}{ Period } & -0.0067 & $-0.00865+$ & $-0.00854+$ \\
\hline & $(0.004)$ & $(0.005)$ & $(0.005)$ \\
\hline
\end{tabular}


Table 5, continued

\begin{tabular}{|c|c|c|c|}
\hline Controls & & & \\
\hline \multirow{2}{*}{ Logged Total PAC Contributions } & $0.00240 * * *$ & $0.00229 * * *$ & $0.00239 * * *$ \\
\hline & $(0.001)$ & $(0.001)$ & $(0.001)$ \\
\hline \multirow[t]{2}{*}{ Quarter Prior to an Election } & -0.00965 & -0.0096 & -0.00877 \\
\hline & $(0.009)$ & $(0.008)$ & $(0.008)$ \\
\hline \multirow[t]{2}{*}{ Regulated Industry } & 0.00524 & 0.00473 & 0.00421 \\
\hline & $(0.005)$ & $(0.005)$ & $(0.005)$ \\
\hline \multirow[t]{2}{*}{ Reputation } & -0.000562 & -0.000523 & -0.000539 \\
\hline & $(0.001)$ & $(0.001)$ & $(0.001)$ \\
\hline \multirow[t]{2}{*}{ Corporate Political Alignment } & $-0.0119 * *$ & $-0.0121 * *$ & $-0.0120 * *$ \\
\hline & $(0.004)$ & $(0.004)$ & $(0.004)$ \\
\hline \multirow[t]{2}{*}{ ROE } & 0.00124 & 0.00095 & 0.00158 \\
\hline & $(0.002)$ & $(0.002)$ & $(0.002)$ \\
\hline \multirow[t]{2}{*}{ Logged Employees } & $0.00317 *$ & $0.00321 *$ & $0.00303 *$ \\
\hline & $(0.001)$ & $(0.001)$ & $(0.001)$ \\
\hline Year Fixed Effects & Yes & Yes & Yes \\
\hline State Fixed Effects & Yes & Yes & Yes \\
\hline Quarter Fixed Effects & Yes & Yes & Yes \\
\hline \multirow[t]{2}{*}{ Constant } & $-0.0175+$ & $-0.0207^{*}$ & $-0.0201 *$ \\
\hline & $(0.010)$ & $(0.010)$ & $(0.010)$ \\
\hline & & & \\
\hline $\mathbf{N}$ & 812 & 812 & 812 \\
\hline
\end{tabular}

$+p<0.10 ; * p<0.05 ; * * p<0.01 ; * * * p<0.001$

Note: Dependent variable is the proportion of contributions refunded 
Table 6: Models Exploring Target-Specific Mechanisms of Nonmarket Disruption

\begin{tabular}{|c|c|c|c|c|}
\hline & $\begin{array}{l}\text { Model 4: } \\
\text { Status }\end{array}$ & $\begin{array}{l}\text { Model 5: } \\
\text { Industry Reg. }\end{array}$ & $\begin{array}{l}\text { Model 6: } \\
\text { Imp. Mgmt }\end{array}$ & $\begin{array}{l}\text { Model 7: } \\
\text { Concession }\end{array}$ \\
\hline \multirow{2}{*}{ Boycott: High Status } & -0.00237 & & & \\
\hline & $(0.006)$ & & & \\
\hline \multirow[t]{2}{*}{ Boycott: Low Status } & -0.00901 & & & \\
\hline & $(0.006)$ & & & \\
\hline Dif: Boycott High Status & $\begin{array}{l}\mathbf{0 . 0 0 9 2 9} \\
(0.009)\end{array}$ & & & \\
\hline Dif: Boycott Low Status & $\begin{array}{l}\mathbf{0 . 0 2 9 4} * * \\
(0.010)\end{array}$ & & & \\
\hline \multirow[t]{2}{*}{ Boycott: Regulated Industry } & & -0.00729 & & \\
\hline & & $(0.009)$ & & \\
\hline \multirow[t]{2}{*}{ Boycott: Unregulated Industry } & & -0.00386 & & \\
\hline & & $(0.006)$ & & \\
\hline \multicolumn{2}{|l|}{ Dif: Boycott Regulated Industry } & $\begin{array}{l}\mathbf{0 . 0 0 8 3 9} \\
(0.009)\end{array}$ & & \\
\hline \multicolumn{2}{|l|}{ Dif: Boycott Unregulated Industry } & $\begin{array}{l}\mathbf{0 . 0 1 8 1} * \\
(0.009)\end{array}$ & & \\
\hline \multirow[t]{2}{*}{ Boycott: High Impression Mgmt } & & & 0.00371 & \\
\hline & & & $(0.008)$ & \\
\hline \multirow[t]{2}{*}{ Boycott: Low Impression Mgmt } & & & $-0.0104+$ & \\
\hline & & & $(0.005)$ & \\
\hline Dif: Boycott High Impression Mgmt & & & $\begin{array}{l}\mathbf{0 . 0 1 2 1} \\
(0.010)\end{array}$ & \\
\hline Dif: Boycott Low Impression Mgmt & & & $\begin{array}{l}\mathbf{0 . 0 2 1 1} * \\
(0.009)\end{array}$ & \\
\hline \multirow[t]{2}{*}{ Boycott: Concession } & & & & 0.00808 \\
\hline & & & & $(0.006)$ \\
\hline \multirow[t]{2}{*}{ Boycott: No Concession } & & & & -0.00229 \\
\hline & & & & $(0.006)$ \\
\hline \multicolumn{4}{|l|}{ Dif: Boycott Concession } & $\begin{array}{l}\mathbf{0 . 0 2 4 1 +} \\
(0.012)\end{array}$ \\
\hline \multicolumn{2}{|l|}{ Dif: Boycott No Concession } & & & $\begin{array}{l}\mathbf{0 . 0 0 8 3 9} \\
(0.007)\end{array}$ \\
\hline
\end{tabular}


Table 6, continued

\begin{tabular}{|c|c|c|c|c|}
\hline Period & $-0.00853+$ & $-0.00865+$ & $-0.00833 *$ & -0.00522 \\
\hline & $(0.005)$ & $(0.005)$ & $(0.004)$ & $(0.004)$ \\
\hline \multicolumn{5}{|l|}{ Controls } \\
\hline \multirow[t]{2}{*}{ Logged Total PAC Contributions } & $0.00240 * * *$ & $0.00244 * * *$ & $0.00243 * * *$ & $0.00245 * * *$ \\
\hline & $(0.001)$ & $(0.001)$ & $(0.001)$ & $(0.001)$ \\
\hline \multirow[t]{2}{*}{ Quarter Prior to an Election } & -0.00843 & $-\mathbf{0 . 0 0 8 9 7}$ & -0.00919 & -0.00905 \\
\hline & $(0.008)$ & $(0.008)$ & $(0.009)$ & $(0.009)$ \\
\hline \multirow[t]{2}{*}{ Regulated Industry } & 0.00546 & 0.00902 & 0.0051 & 0.00525 \\
\hline & $(0.005)$ & $(0.007)$ & $(0.005)$ & $(0.005)$ \\
\hline \multirow[t]{2}{*}{ Company Political Aligment } & $-0.0120 * *$ & $-0.0120 * *$ & $-0.0120 * *$ & $-0.0118 * *$ \\
\hline & $(0.004)$ & $(0.004)$ & $(0.004)$ & $(0.004)$ \\
\hline \multirow[t]{2}{*}{ ROE } & 0.00161 & 0.0016 & 0.00147 & 0.00101 \\
\hline & $(0.002)$ & $(0.002)$ & $(0.002)$ & $(0.002)$ \\
\hline \multirow[t]{2}{*}{ Logged Employees } & $0.00292 *$ & $0.00317 *$ & $0.00278 *$ & 0.00279* \\
\hline & $(0.001)$ & $(0.001)$ & $(0.001)$ & $(0.001)$ \\
\hline \multirow[t]{2}{*}{ Reputation } & & -0.000437 & -0.000697 & -0.000546 \\
\hline & & $(0.001)$ & $(0.001)$ & $(0.001)$ \\
\hline Year Fixed Effects & Yes & Yes & Yes & Yes \\
\hline Quarter Fixed Effects & Yes & Yes & Yes & Yes \\
\hline State Fixed Effects & Yes & Yes & Yes & Yes \\
\hline \multirow[t]{2}{*}{ Constant } & $-0.0235 *$ & $-0.0210 *$ & $-0.0230 *$ & $-0.0179+$ \\
\hline & $(0.009)$ & $(0.010)$ & $(0.010)$ & $(0.010)$ \\
\hline $\mathbf{N}$ & 812 & 812 & 812 & 812 \\
\hline
\end{tabular}

$+p<0.10 ; * p<0.05 ; * * p<0.01 ; * * * p<0.001$

Note: Dependent variable is the proportion of contributions refunded 


\section{References}

ABC News, 2013. "Parents Threaten Victoria's Secret Boycott." Good Morning America. Available at https://gma.yahoo.com/video/gma-parents-threaten-victorias-secret080000252.html.

Baron, D. P. \& Diermeier, D. 2007. "Strategic activism and nonmarket strategy," Journal of Economics and Management Strategy, 16: 599-634.

Baumgartner, F.R., Berry, J.M., Hojnacki, M. \& Kimball, D.C. 2009. Lobbying and Policy Change: Who Wins, Who Loses, and Why. University of Chicago Press.

Bermiss, Y.S., Zajac, E., \& King, B.G. "Under construction: How commensuration and management fashion affect corporate reputation rankings." Organization Science, 25: 591608.

Block, F.L. 1977. "The ruling class does not rule.” Socialist Revolution, 7: 6-28.

Bonardi, J-P, Hillman, A.J. \& Keim, G.D. 2005. "The attractiveness of political markets: Implications for firm strategy." Academy of Management Review, 30: 397-413.

Bonardi, J-P., and Keim, G.D. 2005. "Corporate political strategies for widely salient issues." Academy of Management Review, 30: 555-76.

Burris, V. 2005. "Interlocking directorates and political cohesion among corporate elites." American Journal of Sociology, 111: 249-83.

Burt, R.S. 1992. Structural Holes: The Social Structure of Competition. Cambridge, MA: Harvard University Press.

Carpenter, D.P. 2001. The Forging of Bureaucratic Autonomy: Reputations, Networks, and Policy Innovation in Executive Agencies, 1862-1928. Princeton, NJ: Princeton University Press.

Carroll, G.R., Delacroix, J. \& Goodstein, J. 1988. "The political environments of organizations: An ecological view." Research in Organizational Behavior, 10: 359-92.

Coalition of Immokalee Workers, 2014. "You CAN go home again..." March 11, 2014. Available at http://ciw-online.org/blog/2014/03/you-can-go-home-again/.

Cress, D. \& Snow, D.A. 2000. "The outcomes of homeless mobilization: The influence of organization, disruption, political mediation, and framing." American Journal of Sociology, 105: 1063-1104.

de Figueiredo, J.M. 2009. "Integrated political strategy.” Advances in Strategic Management, 26: 459-86.

de Figueiredo, J.M. \& Silverman, B.S. 2006. "Academic earmarks and the returns to lobbying." Journal of Law and Economics, 49: 597-626.

Danos, P. \& Eichenseher, J. "Audit industry dynamics: Factors affecting changes in clientindustry market shares." Journal of Accounting Research, 20: 604-16.

Dunbar, R.L.M. \& Wasilewski, N. 1985. "Regulating external threats in the cigarette industry." Administrative Science Quarterly, 30: 540-559.

Earl, J., Soule, S.A. \& McCarthy, J.D. 2003 "Protest under fire? Explaining the policing of protest.” American Sociological Review, 68:581-606.

Earl, J., Martin, A., Soule, S.A \& McCarthy, J.D. 2004. "The use of newspaper data in the study of collective action." American Review of Sociology, 30:65-80.

Edelman, L.B., Uggen, C. \& Erlanger, H.S. 1999. "The endogeneity of legal regulation: Grievance procedures as rational myth.” American Journal of Sociology, 105: 406-54. 
Fligstein, N. 1996. "Markets as politics: A political cultural approach to market institutions." American Sociological Review, 50: 377-91.

Fligstein N. \& McAdam, D. 2012. A Theory of Fields. New York: Oxford University Press.

Fombrun, C.J. 1996. Reputation: Realizing Value from the Corporate Image. Boston: Harvard University Press.

Fombrun, C.J. \& Shanley, M. 1990. "What's in a name? Reputation building and corporate strategy." Academy of Management Journal, 33: 233-258.

Gamson, W. 1990. The Strategy of Social Protest. Belmont, CA: Wadsworth.

Getz, K.A. 1997. "Research in corporate political action: Integration and assessment." Business and Society, 36: 32-72.

Greenwood, R., Raynard, M., Kodeih, F., Micelotta, E.R. \& Lounsbury, M. 2011. "Institutional complexity and organizational responses." Academy of Management Annals, 5: 317-71.

Grier, K.B, Munger, M.C. \& Roberts, B.E. 1994. "The determinants of industry political activity, 1978-1986." American Political Science Review, 88: 911-26.

Gulen, H., Cooper, M. \& Schill, M. 2010. "Corporate political contributions and stock returns." Journal of Finance, 65: 687-724.

Hadani, M. \& Schuler, D.A. 2012. "In search of El Dorado: The elusive financial return on corporate political investments.” Strategic Management Journal, 34: 165-81.

Hamm, K., Malbin, M.J., Kettler, J. \& Galvin, B. 2012. "The impact of Citizens United in the states: Independent spending in state elections, 2006-2010." Working Paper.

Hannan, M.T. \& Freeman, J. 1977. "The population ecology of organizations." American Journal of Sociology, 82: 929-96.

Heckman, J.J., Ichimura, H. \& Todd, P. 1998. "Matching as an econometric evaluation estimator." The Review of Economic Studies, 65: 261-294.

Hiatt, S. R. \& Park, S. 2013. "Lords of the harvest: Third-party influence in regulatory approval of genetically modified organisms." Academy of Management Journal, Forthcoming.

Hillman, A.J. 2003. "Determinants of political strategies of US multinationals." Business and Society, 42: 455-84.

Hillman, A.J. 2005. "Politicians on the board of directors: Do connections affect the bottom line?" Journal of Management, 31: 464-81.

Hillman, A.J. \& Keim, G. 1995. "International variation in the business-government interface: Institutional and organizational considerations." The Academy of Management Review, 20: 193-214.

Hillman, A.J. \& Hitt, M.A. 1999. "Corporate political strategy formulation: A model of approach, participation, and strategy decisions." Academy of Management Review, 24: 82542.

Hillman, A.J. Keim, G.D. \& Schuler, D.A. 2004. "Corporate political strategies: A review and research agenda." Journal of Management, 30: 837-57.

Hirsch, P. 1975. "Organizational effectiveness and the institutional environment." Administrative Science Quarterly, 20: 327-44.

Hogan, C.E. \& Jeter, D.C. 1999. "Industry specialization by auditors." Auditing: A Journal of Practice \& Theory, 18: 1-17.

Ingram, P. \& Rao, H. 2004. "Store wars: The enactment and repeal of anti-chain-store legislation in America." American Journal of Sociology, 110: 446-87.

Ingram, P., Yue, L.W., \& Rao, H. 2010. "Trouble in store: Probes, protests and store openings by Wal-Mart: 1998-2005.” American Journal of Sociology, 116: 53-92. 
King, B.G. 2008. "A political mediation model of corporate response to social movement activism." Administrative Science Quarterly, 53: 395-421.

King, B.G. 2011. "The tactical disruptiveness of social movements: Sources of market and mediated disruption in corporate boycotts." Social Problems, 58: 491-517.

King, B.G. \& Soule, S.A. 2007. "Social movements as extra-institutional entrepreneurs: The effect of protests on stock price returns." Administrative Science Quarterly, 52: 413-42.

King, B.G., Felin, T. \& Whetten, D. 2010. "Finding the organization in organizational theory: A meta-theory of the organization as a social actor." Organization Science, 21: 290-305.

King, B.G. \& McDonnell, M.-H. 2014. "Good firms, good targets: The relationship between corporate social responsibility, reputation, and activist targeting." Forthcoming in K. Tsutsui \& A. Lim (eds.), Corporate Social Responsibility in a Globalizing World: Toward Effective Global CSR Frameworks, Cambridge University Press.

Koopmans, R. \& Olzak, S. 2004. "Discursive opportunities and the evolution of right-wing violence in Germany." American Journal of Sociology, 110: 198-230.

Levinthal, D. 2012. "How corporate PACs handle bad PR." Politico.com, 30 July.

Lindblom, C.E. 1977. Politics and Markets: The World's Political-Economic Systems. New York: Basic Books.

Linblom, C.E. 1982. “The market as prison.” Journal of Politics, 44: 324-36.

Luders, J. 2006. "The economics of movement success: Business responses to civil rights mobilization." American Journal of Sociology, 111: 963-98.

Macher, J.T., Mayo, J.W. \& Schiffer, M. 2011. "The influence of firms on government." B.E. Journal of Economic Analysis and Policy (Contributions), 11: Article 1.

Macher, J.T. \& Mayo, J.W. 2012. "The world of regulatory influence." Journal of Regulatory Economics, 41: 59-79.

Marquis, C. \& Qian, C. 2014. "Corporate social responsibility reporting in China: Symbol or substance?," Organization Science, 1: 127-48.

Mayhew, D.R. 1974. Congress: The Electoral Connection. New Haven: Yale University Press.

McAdam, D. and Su, Y. 2002. "The war at home: Antiwar protests and congressional voting, 1665 to 1973." American Sociological Review, 67: 696-721.

McDonnell, M.-H. \& King, B.G. 2013. "Keeping up appearances: Image threats and impression management after social movement attacks," Administrative Science Quarterly, 58: 387419.

McDonnell, M.-H. \& King, B.G. 2014. "Taxing a tarnished halo: Reputation and ambiguity in punishment of corporate transgressions." Working Paper.

McDonnell, M.-H., King, B.G., \& Soule, S.A. 2014. "A dynamic process model of contentious politics: Activist targeting and corporate receptivity to social challenges." Working Paper.

Mizruchi, M. \& Koenig, T. 1986. "Economic sources of corporate political consensus: An examination of interindustry relations." American Sociological Review, 51: 482-491.

Mizruchi, M.S. 1989. "Similarity of political behavior among large American corporations." American Journal of Sociology, 95: 401-24.

Mizruchi, M.S. 1992. The Structure of Corporate Political Action: Interfirm Relations and Their Consequences. Cambridge, MA: Harvard University Press.

Mullins, B. \& Spencer, J. 2010. "Obama to keep Goldman funds.” Wall Street Journal, 21 April.

Oliver, P.E. \& Myers, D.J. 1999. "How events enter the public sphere: Conflict, location, and sponsorship in local newspaper media coverage of public events." American Journal of 
Sociology, 105: 38-87.

Oliver, P.E. \& Maney, G.M. 2000. "Political processes and local newspaper coverage of protest events: From selection bias to triadic interactions." American Journal of Sociology, 106: 463-505.

Oliver, C.Y. \& Holzinger, I. 2008. "The effectiveness of strategic political management: A dynamic capabilities framework." Academy of Management Review, 33: 496-520.

Ortiz, D.G., Myers, D.J., Walls, N.E. \& Diaz, M.E.D. 2005. "Where do we stand with newspaper data?" Mobilization, 10: 397-419.

Papke, L.E. \& Wooldridge, J.M. 1996. "Econometric methods for fractional response variables with an application to 401(k) plan participation rates." Journal of Applied Econometrics, 11: 619-32.

Pfarrer, M.D., Pollock, T.G. \& Rindova, V.P. 2010. "A tale of two assets: The effects of reputation and celebrity on earnings surprises and investors' reactions." Academy of Management Journal, 53: 1131-52.

Pfeffer, J. \& Salancik, G.R. 1978. The External Control of Organizations. New York: Harper \& Row.

Piven, F.F. \& Cloward, R.A. 1977. Poor People's Movements: Why They Succeed, How They Fail. Edited by Anonymous. New York: Pantheon Books.

Polanyi, K. 1957. "The economy as an instituted process." In K. Polanyi, C.M. Arensbert, and H.W. Pearson (eds.), Trade and Market in the Early Empires: Economies in History and Theory. New York: Free Press.

Pontikes, E., Negro, G. \& Rao, H. 2010. "Stained red: A study of stigma by association to blacklisted artists during the 'red scare' in Hollywood, 1945 to 1960." American Sociological Review, 75: 456-78.

Rao, H., Yue, L.Q. \& Ingram, P. 2011. "Laws of attraction: Regulatory arbitrage in the face of activism in right-to-work states." American Sociological Review, 76: 365-385.

Richter, B.K. \& Werner, T. 2013. "Campaign contributions from corporate executives in lieu of political action committees." Working Paper.

Roberts, P.W. \& Dowling, G.R. 2002. "Corporate reputation and sustained superior financial performance," Strategic Management Journal, 23: 1077-93.

Rojas, F. 2006. "Social movement tactics, organizational change, and the spread of AfricanAmerican studies." Social Forces, 84: 2147-66.

Sabate, J.M.F. \& Puente, E.Q. 2003. "Empirical analysis of the relationship between corporate reputation and financial performance: A survey of the literature." Corporate Reputation Review, 6: 161-77.

Schuler D.A., Rehbein K.A. \& Cramer, R . 2002. "Pursuing strategic advantage through political means: A multivariate approach." Academy of Management Journal, 45: 659-73.

Scott, W.R. 1982. "The adolescence of institutional theory." Administrative Science Quarterly, 32: 493-511.

Scott, W.R. 2001. Institutions and Organizations, Thousand Oaks, CA: Sage.

Siedman. G. W., 2007. Beyond the Boycott: Labor Rights, Human Rights, and Transnational Activism, New York, NY: Russell Sage Foundation.

Skocpol, T. 1985. "Bringing the state back in: Strategies for analysis in current research." In P. Evans, D. Rueschemeyer \& T. Skocpol (Eds.), Bringing the State Back In. New York: Cambridge University Press, 3-43. 
Smith, M.A. 2000. American Business and Political Power: Public Opinion, Elections, and Democracy. Chicago: University of Chicago Press.

Smith, M.A. 2007. The right talk: How conservatives transformed the great society into the economic society. Princeton: Princeton University Press.

Soule, S.A. 2009. Contention and Corporate Social Responsibility, New York: Cambridge University Press.

Soule, S.A., Swaminathan, A. \& Tihanyi, L. 2013. "The diffusion of foreign divestment from Burma." Strategic Management Journal, Forthcoming.

Suchman, M.C. 1995. "Managing legitimacy: Strategic and institutional approaches," Academy of Management Review, 20: 571-610.

Van Dyke, N., S.A. Soule, and V.A. Taylor. 2004. "The targets of social movements: Beyond a focus on the state." Research in social movements, conflicts, and change, 25:27-51.

Vasi, I. B. \& King, B.G. 2013. "Social movements, risk perceptions, and economic outcomes: the effect of primary and secondary activism on firms' perceived environmental risk and financial performance." American Sociological Review, 77: 573-596.

Walker, E.T. 2014. Grassroots for hire: Public affairs consultants in American democracy. Cambridge, UK: Cambridge University Press.

Walker, E.T. \& Rea, C.M. 2014. "The political mobilization of firms and industries." Annual Review of Sociology, Forthcoming.

Weiss, L.W. \& Klass, M.W. 1986. Regulatory Reform: What Actually Happened. LittleBrown, Boston, MA.

Werner, T. 2014. "Gaining access by doing good: The effect of sociopolitical reputation on firm participation in public policymaking." Management Science, Forthcoming.

Werner, T. \& Coleman, J.J. 2014. "Citizens United, independent expenditures, and agency costs: Reexamining the political economy of state antitakeover statutes." Journal of Law, Economics, and Organization, Forthcoming.

Weymouth, S. 2012. "Firm lobbying and influence in developing countries: A multi-level approach." Business and Politics, 14: 1-26. 